\title{
Çevrimiçi ölçme ve değerlendirmeye yönelik özyeterlik ölçeğinin geliştirilmesi
}

\author{
Development of the self-efficiency scale for online measurement and evaluation \\ Adem Koç ${ }^{1}$, Nezaket Bilge Uzun² ve Mutlu Nisa Ünaldı Coral ${ }^{3}$ \\ ${ }^{1}$ Araş. Gör., Mersin Üniversitesi, Mersin/Türkiye, e-mail: ademkoc@mersin.edu.tr ORCID: https://orcid.org/0000-0002-2721-3781 \\ ${ }^{2}$ Doç. Dr., Mersin Üniversitesi, Mersin/Türkiye, e-mail: buzun@mersin.edu.tr ORCID: https://orcid.org/0000-0003-2293-4536 \\ ${ }^{3}$ Prof. Dr., Mersin Üniversitesi, Mersin/Türkiye, e-mail: mutlunisa@mersin.edu.tr ORCID: https://orcid.org/0000-0001-6124-4576
}

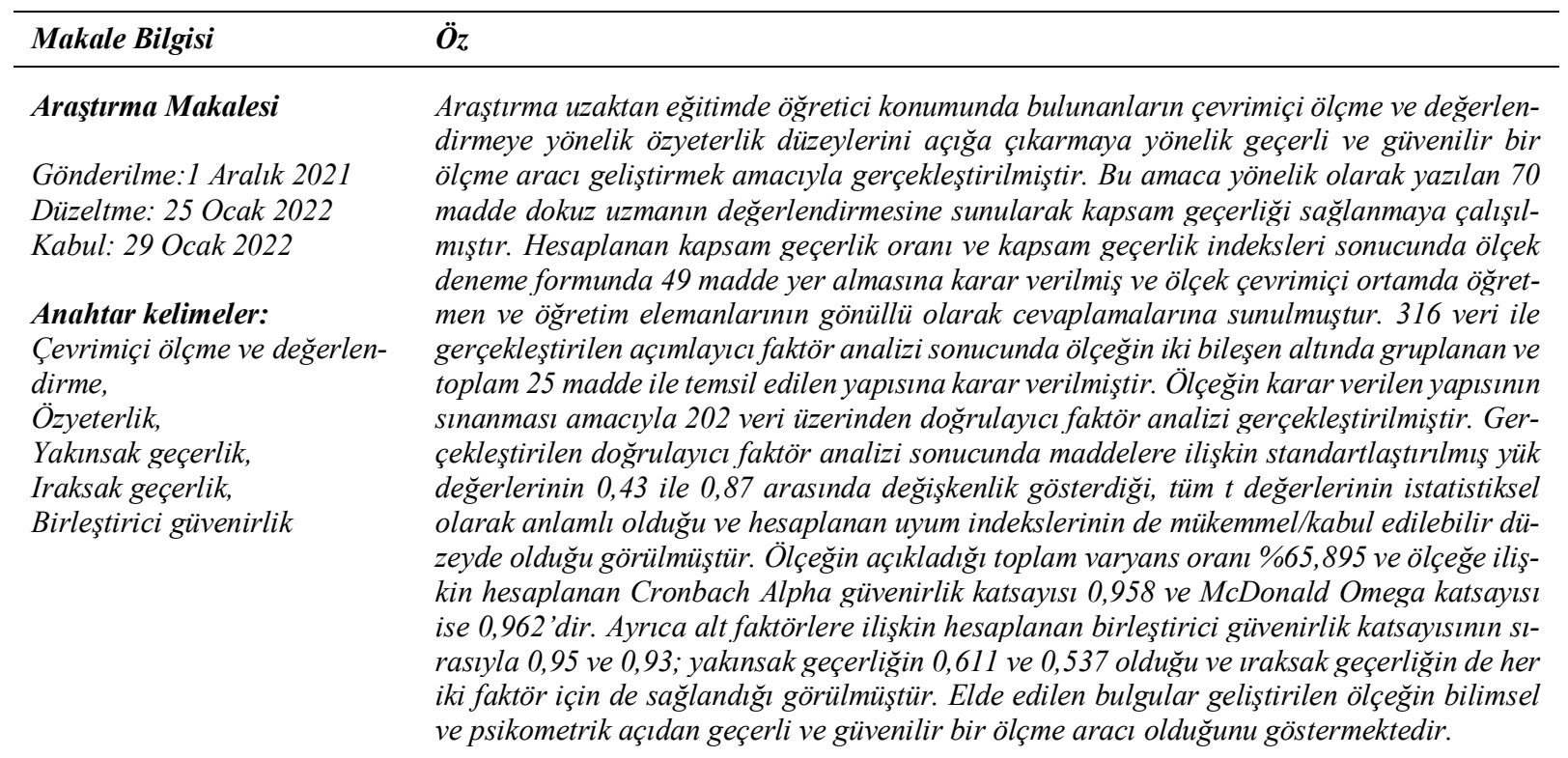

\begin{tabular}{|c|c|}
\hline Article Info & Abstract \\
\hline $\begin{array}{l}\text { Research Article } \\
\text { Received: } 1 \text { December } 2021 \\
\text { Revised: } 25 \text { January } 2022 \\
\text { Accepted: } 29 \text { January } 2022 \\
\text { Keywords: } \\
\text { Online assessment and evalu- } \\
\text { ation, } \\
\text { Self-efficacy, } \\
\text { Convergent validity, } \\
\text { Divergent validity, } \\
\text { Composite reliability }\end{array}$ & $\begin{array}{l}\text { The research was carried out with the aim of developing a valid and reliable measurement } \\
\text { tool to reveal the self-efficacy levels of those who are in the position of instructors in distance } \\
\text { education for online measurement and evaluation. The content validity was tried to be en- } \\
\text { sured by submitting the } 70 \text { items written for this purpose to the evaluation of nine experts. } \\
\text { As a result of the calculated content validity rate and content validity indexes, it was decided } \\
\text { to include } 49 \text { items in the scale trial form and the scale was submitted to the online environ- } \\
\text { ment for teachers and lecturers to respond voluntarily. As a result of the exploratory factor } \\
\text { analysis performed with } 316 \text { data, the structure of the scale grouped under two components } \\
\text { and represented by a total of } 25 \text { items was decided. Confirmatory factor analysis was per- } \\
\text { formed on } 202 \text { data in order to test the decision-making structure of the scale. As a result of } \\
\text { the confirmatory factor analysis, it was seen that the standardized load values for the items } \\
\text { varied between } 0.43 \text { and } 0.87 \text {, all t values were statistically significant and the calculated fit } \\
\text { indices were also excellent/acceptable. The total variance rate explained by the scale is } \\
65.895 \% \text {, and the Cronbach Alpha reliability coefficient calculated for the scale is } 0.958 \\
\text { and the McDonald Omega coefficient is } 0.962 \text {. In addition, the composite reliability calcu- } \\
\text { lated for the sub-factors is } 0.95 \text { and } 0.93 \text {, respectively; It was seen that the convergent va- } \\
\text { lidity was } 0.611 \text { and } 0.537 \text { and the divergent validity was provided for both factors. The } \\
\text { findings obtained show that the developed scale is scientifically and psychometrically valid } \\
\text { and reliable. }\end{array}$ \\
\hline
\end{tabular}

*Bu çalışmanın Etik Kurul Onayı, 05.04.2021 tarih ve 04 sayll karar ile Mersin Üniversitesi Sosyal ve Beşeri Bilimler Etik Kurulu'ndan alınmıștır. Tüm sorumluluk yazara aittir.

Kaynak göster: Koç, A., Uzun, N.B. \& Ünaldı Coral, M.N. (2022). Çevrimiçi ölçme ve değerlendirmeye yönelik özyeterlik ölçeğinin geliştirilmesi. International Journal of Social Sciences and Education Research, 8 (1), 87-98. DOI: https://doi.org/10.24289/ijsser.1031155 


\section{Giris}

Çin Halk Cumhuriyeti'nin Wuhan kentinde başlayan Covid-19 salgını kısa sürede tüm dünyada hayatı olumsuz etkilemiştir. Dünya üzerinde ülkeler arası ticaret ve seyahat durma noktasına gelmiş, iş yerleri ve fabrikalar kapanmış, birçok insan işsiz kalmıştır. Sosyal hayatı derinden etkileyen salgın sürecinden eğitim öğretim de etkilenmiş ve ülkemiz özelinde bakıldığında 16 Mart 2020 itibarıyla ilk ve ortaokullar, 23 Mart 2020 itibarıyla da üniversiteler eğitim öğretime ara vermek zorunda kalmıştır. Bu tarihlerden sonra eğitim öğretime çeşitli platformlar üzerinden uzaktan devam etmeye karar verilerek uygulanmaya başlanmıştır (Sarı, 2020).

Önceleri ayrı bir tercih ya da destek olarak kullanılan uzaktan eğitim Covid-19 döneminde tüm eğitim öğretim kademelerinde uygulanmaya başlanmak zorunda kalınmıştır. Bu süreçte uzaktan eğitimde derslerin senkron ya da asenkron olarak gerçekleştirildiği görülmekle birlikte öğretim kalitesinin denetlenebilirliği, eğitim hedeflerinin ölçülebilirliği ve sürdürülebilirliği konusunda endişe oluşmuştur. Uzaktan eğitim sürecinin ağıllıklı olarak devam ettiği süreçte ölçme değerlendirmeye gereken önemi vermemek, rasgele not vererek öğrenci başarısını gerektiği gibi ölçmemek, herkese aynı notları vererek dersten geçirmek ileride öğrenciler hakkında verilecek kararları da önemli ölçüde etkileyecektir (Sarı, 2020). Bu bağlamda eğitim öğretimin uzaktan sürdürüldüğü dönemlerde de ölçme ve değerlendirme yaklaşımlarının eğitim felsefesine uygun olarak gerekli önemin verilmesi ve etkin bir şekilde gerçekleştirilmesi gerektiği aşikârdır.

E-öğrenme ya da çevrimiçi öğrenme olarak da adlandırılan uzaktan eğitimde gerçekleştirilen ölçme değerlendirme faaliyetlerinin de genel olarak çevrimiçi ölçme değerlendirme olarak ifade edildiği görülmektedir (Balta ve Türel, 2013; Kocatürk Kapucu ve Adnan, 2018). Çevrimiçi öğretme öğrenme sürecinde gerçekleştirilen ölçme değerlendirme faaliyetlerinin de doğal olarak normalden farklı olarak gerçekleşmesi beklenmektedir. Çevrimiçi eğitim öğretim sürecinde gerçekleştirilecek ölçme değerlendirme faaliyetlerinin süreklilik içermesi gerekmektedir. Süreklilik geri dönüt sağlama, öğrenme hızlarındaki farklılıklar ve değerlendirme süreci sonunda elde edilen niteliklerin kontrol edilebilmesi açısından oldukça önemlidir ve eğitim öğretim sürecinde herhangi bir aksama ya da eksiklik yaşanmasını engellemektedir (Balta ve Türel, 2013). Bu süreçte öğreticilerin öğretim süreci öncesinde, öğretim sürecinde ve öğretim süreci sonunda gerçekleştirmeleri gereken birtakım görevler bulunmaktadır. Öğretim süreci öncesinde süreçte kullanacağı malzeme ve materyalleri e-içerikler haline dönüştürerek çeşitli ödev, proje ya da etkinliklerle zenginleştirmesi, süreçte kullanacă̆ öğretim yöntem ve teknikler ile ölçme değerlendirme faaliyetlerinden öğrencileri haberdar etmesi beklenmektedir. Öğretim sürecinde öğrencileri etkin bir şekilde izleyerek geri dönüt sağlamalı ve öğrenme hızlarını kontrol altında tutmalı, öğrenme süreci sonunda ise notlandırma ve değerlendirme faaliyetlerini etkin bir şekilde gerçekleştirebilmelidir (Gülbahar, 2012).

Tüm bu faaliyetlerin gerçekleştirilebilmesi de şüphesiz ki öncelikle bu faaliyetlere yönelik öğreticilerin sahip olması gereken öz yeterlik ile mümkün olacaktır. Öyle ki, öz yeterliğin en genel tanımı ile 'bireyin bir işi başarılı bir şekilde yapabilmesi için o işin gerektirdiği donanıma sahip olduğu konusundaki inancı' şeklinde ifade edildiği görülmektedir (Bandura, 1986). Literatürde yer alan diğer öz yeterlik tanımlarının da bu çerçevede geliştiği ve bireyin bir işi gerçekleştirebilecek donanıma sahip olmasına rağmen gerçekleştirmeye yönelik inancı olmaması durumunda başarıya ulaşamama olasılı̆̆ının yüksek olduğunun ifade edildiği görülmektedir (Gawith, 1995). Bu bağlamda uzaktan eğitim sürecinde çevrimiçi ölçme değerlendirme faaliyetlerinin etkin bir şekilde gerçekleştirilebilmesi de öğreticilerin çevrimiçi ölçme değerlendirme faaliyetlerini gerçekleştirmeye yönelik öz yeterlikleri ölçüsünde başarıya ulaşacağı düşünülmektedir.

$\mathrm{Bu}$ çerçevede bu çalışmanın amacı uzaktan eğitim sürecinde öğretici konumunda bulunanların çevrimiçi ölçme ve değerlendirmeye ilişkin öz yeterliklerini açığa çıkarmaya yönelik geçerli ve güvenilir bir ölçme aracı geliştirmektir.

Çevrimiçi Ölçme ve Değerlendirme (ÇÖD): Bilgi ve iletişim teknolojileri kullanılarak sanal ortamda gerçekleştirilen her türlü ölçme ve değerlendirme işlemidir (Balta ve Türel, 2013; Kocatürk Kapucu ve Adnan, 2018).

Çevrimiçi Ölçme ve Değerlendirmeye Yönelik Özyeterlik (ÇÖDYÖ): Bireyin, bilgi ve iletişim teknolojileri kullanılarak sanal ortamda gerçekleştirilen ölçme ve değerlendirme faaliyetlerini etkili bir şekilde gerçekleştirebileceğine yönelik inancı olarak tanımlanabilmektedir.

Çevrimiçi eğitim öğretim faaliyetlerinin ölçme ve değerlendirme etkinliklerinin de çevrimiçi ortamlarda yapılma gerekliliğinin ortaya çıktığı Covid-19 salgını sürecinde, çevrimiçi eğitim öğretimde öğretici konumunda bulunanların çevrimiçi ölçme değerlendirmeye yönelik özyeterlikleri de ön plana çıkmıştır. Çevrimiçi ölçme değerlendirme faaliyetlerinin sağlıklı bir şeklide sürdürülebilmesi için bu anlamda öğretici konumunda bulunanların 
özyeterliklerinin önemli olduğu düşünülmektedir. Bu bağlamda uzaktan eğitimde öğretici konumunda bulunanların özyeterliklerini açığa çıkarmayı amaçlayan bu çalışmanın literatüre katkı sağlayacağı düşünülmektedir.

\section{Yöntem}

Gerçekleştirilen araştırmanın bu bölümünde çalışma grubu ve çevrimiçi ölçme ve değerlendirmeye yönelik özyeterlik ölçeğinin geliştirilme süreci ile verilerin analizi açıklanmıştır. Bu çalışmanın Etik Kurul Onayı, 05.04.2021 tarih ve 04 sayılı karar ile Mersin Üniversitesi Sosyal ve Beşeri Bilimler Etik Kurulu’ndan alınmıştır

\section{1. Çalışma grubu}

Araştırmada veriler 2020-2021 eğitim öğretim yılı güz döneminde çevrimiçi eğitim sistemleri üzerinden ders vermekte olan öğretmen ve öğretim elemanlarından elde edilmiştir. Yüz yüze veri toplamanın mümkün olmadığı Covid-19 salgını sürecinde, çevrimiçi olarak oluşturulan ölçek deneme formu ulaşılabilen tüm öğretmen ve öğretim elemanlarına gönderilerek gerekli açıklamalar yapılmış ve çalışmaya gönüllü katıldıklarını taahhüt etmeleri durumunda formu yanıtlamaları istenmiştir. Bu bağlamda öncelikle açımlayıcı faktör analizinin sayıltılarını test etmek amaciyla 348 veri elde edilmiş ve gerçekleştirilen ön analizler sonucunda 316 veri ile analizlere devam edilmiştir. Gerçekleştirilen alanyazın taramasında açımlayıcı faktör analizi için 300 verinin yeterli olduğunun ifade edilmesi (Tabachnick and Fidel, 2015) bu kriterin sağlandığını göstermektedir. Karar verilen yapının sınanması için ise benzer özelliklere sahip bağımsız bir çalışma grubundan 219 veri elde edilmiş ve ön analizler sonucunda kalan 202 veri üzerinden analizler gerçekleştirilmiştir. Tablo 1'de açımlayıcı faktör analizi (AFA) ve doğrulayıcı faktör analizi (DFA) için gerçekleştirilen veri toplama süreci sonucunda elde edilen gözlemlerin belirlenen çeşitli demografik özelliklere göre dağılımına ilişkin frekans ve yüzde değerleri verilmiştir.

Tablo 1. AFA ve DFA çalışma grubunun bazı demografik özelliklere göre dağılımı

\begin{tabular}{|c|c|c|c|c|c|c|c|}
\hline \multicolumn{4}{|c|}{ AFA çalışma grubu } & \multicolumn{4}{|c|}{ DFA çalışma grubu } \\
\hline Değişken & Kategori & $\mathrm{F}$ & $\%$ & Değişken & Kategori & $\mathrm{F}$ & $\%$ \\
\hline \multirow{5}{*}{ Kidem y1lı } & $1-5$ & 142 & 40,8 & \multirow{5}{*}{ Kidem yilı } & $1-5$ & 98 & 44,8 \\
\hline & $6-10$ & 106 & 30,5 & & $6-10$ & 50 & 22,8 \\
\hline & $11-15$ & 72 & 20,7 & & $11-15$ & 52 & 23,7 \\
\hline & $16-20$ & 16 & 4,6 & & $16-20$ & 10 & 4,6 \\
\hline & $20+$ & 12 & 3,4 & & $20+$ & 9 & 4,1 \\
\hline \multirow{2}{*}{ Cinsiyet } & Erkek & 114 & 32,8 & \multirow{2}{*}{ Cinsiyet } & Erkek & 98 & 44,7 \\
\hline & Kadın & 234 & 67,2 & & Kadın & 121 & 55,3 \\
\hline \multirow{11}{*}{$\begin{array}{l}\text { Branş/ } \\
\text { uzmanlık } \\
\text { alanı }\end{array}$} & Fen bilgisi öğretmenliği & 116 & 33,3 & \multirow{11}{*}{$\begin{array}{l}\text { Branş/ } \\
\text { uzmanlık } \\
\text { alanı }\end{array}$} & Fen bilgisi öğretmenliği & 52 & 23,7 \\
\hline & $\begin{array}{l}\text { Matematik/ilköğretim mate- } \\
\text { matik öğretmenliği }\end{array}$ & 50 & 14,3 & & $\begin{array}{l}\text { Matematik/ilköğretim mate- } \\
\text { matik öğretmenliği }\end{array}$ & 33 & 15,1 \\
\hline & Sinıf ögretmenliği & 38 & 11,2 & & Sınıf öğretmenliği & 27 & 12,3 \\
\hline & Türkçe öğretmenliği & 40 & 11,5 & & Türkçe öğretmenliği & 29 & 13,2 \\
\hline & Sosyal bilg. Öğretmenliği & 14 & 4,0 & & Sosyal bilg. Öğretmenliği & 13 & 5,9 \\
\hline & İngilizce öğretmenliği & 42 & 12,1 & & İngilizce öğretmenliği & 25 & 11,4 \\
\hline & Biyoloji öğretmenliği & 12 & 3,4 & & Biyoloji öğretmenliği & 11 & 5,1 \\
\hline & Fizik öğretmenliği & 13 & 3,7 & & Fizik öğretmenliği & 10 & 4,6 \\
\hline & Kimya öğretmenliği & 13 & 3,7 & & Kimya öğretmenliği & 11 & 5,1 \\
\hline & Eğitimde ölçme ve değ. & 6 & 1,7 & & Eğitimde ölçme ve değ. & 4 & 1,8 \\
\hline & Eğitim yönetimi & 4 & 1,1 & & Eğitim yönetimi & 4 & 1,8 \\
\hline \multirow{3}{*}{$\begin{array}{l}\text { Öğrenim } \\
\text { durumu }\end{array}$} & Lisans & 240 & 69,0 & \multirow{3}{*}{$\begin{array}{l}\text { Öğrenim } \\
\text { durumu }\end{array}$} & Lisans & 122 & 55,7 \\
\hline & Y. Lisans & 70 & 20,1 & & Y. Lisans & 69 & 31,5 \\
\hline & Doktora & 38 & 10,9 & & Doktora & 28 & 12,8 \\
\hline \multirow{4}{*}{$\begin{array}{l}\text { Öğretimin } \\
\text { gerçekleşti- } \\
\text { rildiği okul } \\
\text { düzeyi }\end{array}$} & İlkokul & 38 & 10,9 & \multirow{4}{*}{$\begin{array}{l}\text { Öğretimin } \\
\text { gerçekleşti- } \\
\text { rildiği okul } \\
\text { düzeyi }\end{array}$} & İlkokul & 27 & 12,3 \\
\hline & Ortaokul & 196 & 56,3 & & Ortaokul & 98 & 44,8 \\
\hline & Lise & 72 & 20,7 & & Lise & 67 & 30,6 \\
\hline & Üniversite & 42 & 12,1 & & Üniversite & 27 & 12,3 \\
\hline \multicolumn{2}{|l|}{ Toplam } & 348 & 100 & \multicolumn{2}{|l|}{ Toplam } & 219 & 100 \\
\hline
\end{tabular}

Tablo 1 incelendiğinde açımlayıcı faktör analizinin gerçekleştirildiği çalışma grubunun 348 kişiden oluştuğu görülmektedir. Çalışma grubunu oluşturan 348 kişinin cinsiyete göre dağılımının 114 (\%32.8) erkek ve 234 (\%67.2) kadın şeklinde gerçekleştiği görülmektedir. Uzmanlık alanlarına göre 11 farklı alanda dağılım gösteren çalı̧̧ma grubunun en yüksek oranda fen bilgisi eğitimi (\%33.3) alanında uzman kişilerden oluştuğu görülmektedir. Bu bağlamda açımlayıcı faktör analizine ilişkin çalışma grubunu oluşturan katılımcıların diğer demografik özelliklere göre dağılımlarına ilişkin frekans ve yüzde değerleri de Tablo 1'de gösterildiği şekilde gerçekleşmiştir. Copyright $(\mathrm{C} 2022$ by IJSSER

ISSN: 2149-5939 
Ayrıca doğrulayıcı faktör analizinin gerçekleştirildiği çalışma grubuna yönelik olarak Tablo 1 incelendiğinde ilgili çalışma grubunun 219 kişiden oluştuğu görülmektedir. Çalışma grubunu oluşturan 219 kişinin cinsiyete göre dağılımının 98 (\%44.7) erkek ve 121 (\%55.3) kadın şeklinde gerçekleştiği görülmektedir. Açımlayıcı faktör analizine ilişkin çalışma grubu ile benzer şekilde, uzmanlık alanlarına göre 11 farklı alanda dağılım gösteren çalışma grubunun en yüksek oranda yine fen bilgisi eğitimi (\%23.7) alanında uzman kişilerden oluştuğu görülmektedir. Bu bağlamda doğrulayıcı faktör analizine ilişkin çalışma grubunu oluşturan katılımcıların diğer demografik özelliklere göre dağılımlarına ilişkin frekans ve yüzde değerleri de Tablo 1'de gösterildiği gibidir.

\section{2. Çevrimiçi ölçme ve değerlendirmeye yönelik özyeterlik ölçeği geliş̧irme süreci}

Bu bağlamda geliştirilecek ölçme aracına ilişkin öncelikle madde havuzunun ve sonrasında deneme formunun oluşturulması sürecinde ilk olarak çevrimiçi ölçme değerlendirmeye ilişkin literatür taraması gerçekleştirilmiştir. $\mathrm{Bu}$ aşamada literatüre ek olarak olası alt faktörlerin belirlenmesi, ilgili demografik özelliklere karar verilebilmesi ve olası madde önerilerinin alınmasına yönelik olarak uzman görüşlerine başvurulmuştur. Gerçekleştirilen literatür taraması ve uzman görüş formlarının değerlendirilmesi sonucunda araştırmacılar tarafından 70 madde yazılmıştır. Deneme formunun oluşturulmasına yönelik yazılan maddeler ölçme değerlendirme ve fen bilimleri eğitimi alanında olmak üzere toplam 9 uzman görüşüne sunulmuştur.

Buna göre; toplam 70 madde uzman görüşüne sunulmuş ve dokuz uzmanın görüşleri toplanmıştır. Bu görüşler çerçevesinde kapsam geçerlik oranları ve kapsam geçerlik indeksleri hesaplanmıştır. Hesaplanan kapsam geçerlik oranlarının 0,11 ile 1,00 arasında değişkenlik gösterdiği görülmektedir. Veneziano ve Hooper'ın (1997) ölçütleri dikkate alındığında dokuz uzmanın var olduğu durumda ilgili uygunluk ölçütü 0,75 'tir. Bu bağlamda kapsam geçerlik oranı 0,75 ve üzerinde bulunan toplam 49 madde doğrudan, ya da uzman görüşlerine göre küçük düzenlemelerle, deneme formuna alınmış, bu değerin altında yer alan maddelerin tamamı da deneme formundan çıkarılmıştır. Sonuçta 49 maddeden oluşan bir deneme formu oluşturulmuştur. Deneme formunda yer alan maddelerin kapsam geçerlik oranlarının ortalaması olarak hesaplanan kapsam geçerlik indeksi ise 0,91 olarak hesaplanmıştır. KGİ $>$ KGO olduğu için de kapsam geçerlik indeksi tüm ölçek için istatiksel olarak anlamlıdır (Yurdugül, 2005) şeklinde yorumlanmıştır. Bandura (2005), çok sayıda derecelendirmeye sahip ölçeklerin daha duyarlı ve güvenilir ölçümler yapacağını belirterek özyeterlik ölçeklerinde çok sayıda derecelendirmeye yer verilmesini önermektedir. $\mathrm{Bu}$ bağlamda oluşturulan form için katılımcılardan formda yer alan her bir maddenin yanıtlanmasında kendilerini 0 ile 100 arasında 10 'ar puanlık skala ile değişen derecelerden uygun olanı ile değerlendirmeleri beklenmektedir.

\subsection{Verilerin analizi}

$\mathrm{Bu}$ araşıırmada geliştirilen ölçme aracının yapısının ortaya konulmasında açımlayıcı faktör analizi ve bu yapının doğrulanmasında doğrulayıcı faktör analizi gerçekleştirilmiştir. DFA için elde edilen veriler üzerinden faktörler içerisinde yer alan maddelerin ilişkisi hakkında bilgi veren yakınsak ve ıraksak geçerlik; benzer ifadelere yönelik genel güvenirliğin bir ölçüsü olarak kabul edilen birleştirici güvenirlik (CR) değeri (Raykov, 1998) değerleri hesaplanmıştır. Ayrıca yapının belirlenmesine ek kanıt olarak Horn'un paralel analizi (1965) kullanılmıştır. Ölçme aracının geliştirilmesi sürecinde açımlayıcı faktör analizine ilişkin elde edilen veriler SPSS 22.0 programı ile doğrulayıcı faktör analizine ilişkin bulgular ise Lisrel 8.71 programı ile bilgisayar ortamında analiz edilmiştir. Ölçeğin yapısını ortaya çıkartmak amacıyla açımlayıcı faktör analizi gerçekleştirilmiştir. Çok değişkenli bir istatistiksel teknik olan açımlayıcı faktör analizi, birbiriyle ilişkili olan çok sayıdaki değişkeni bir araya getirerek, kavramsal olarak anlamlı daha az sayıda değişken oluşturmayı amaçlamaktadır (Büyüköztürk, 2014).

Ölçeğin yapı ve kapsam geçerliliğin sağlanması açısından uzman görüşleri alınarak hazırlanan ve 49 maddeden oluşan deneme formu çevrimiçi ortamda uzaktan eğitimde öğretici konumunda bulunan öğretmen ve öğretim elemanlarının yanıtlamasına sunulmuştur. Toplam 348 katılımcının cevaplarından oluşan deneme formuna ilişkin veri setinde eksik ya da hatalı veriye rastlanmamıştır. Verilerin analizi bölümünde de belirtildiği üzere çok değişkenli aykırı değerlerin incelenmesi amacıyla da mahalanobis uzaklıklarının hesaplanması sonucunda 30 adet gözlem çok değişkenli aykırı değer olması nedeniyle $(\chi 2(49 ; 0,001)=85,331)$ veri setinden çıkarılmıştır. Ayrıca tek değişkenli aykırı değerler için $\mathrm{Z}$ puanları hesaplanmış ve $[-4,+4]$ aralığında olmadığı görülen iki adet gözlem tek değişkenli aykırı değer olması nedeniyle veri setinden çıkarılmıştır (Tabachnick ve Fidell, 2015). Devamında tolerans ve VIF değerleri hesaplanarak çoklu bağlantı problemini test edilmiştir. Hesaplamalar sonucunda elde edilen tolerans değerlerinin 0,076 ile 0,406 arasında; vif değerlerinin de 2,465 ile 13,146 arasında değiştiği görülmüştür. Maddelerin çoklu bağlantı problemi göstermemesi için tolerans değerinin 0,20 'den büyük olması ve vif değerlerinin de 5'ten küçük olması beklenmektedir (Tabachnick ve Fidell, 2015). Bu durumda çoklu bağlantı problemi gösterdiği tespit edilen toplam 22 madde deneme formundan çıarılmış ve deneme formunda kalan 27 madde ile analizlere devam edilmiştir. Hataların bağımsızlı̆̆ınının sınanması amacıyla Durbin Watson katsayısı değerinin Copyright $\mathbb{C} 2022$ by IJSSER

ISSN: 2149-5939 
2,50 civarı değerler alması beklenen bir durumdur (Tabachnick ve Fidell, 2015). Bu bağlamda hesaplanan değerin yaklaşık 3,00 olduğu görülmüş ve kabul edilebilir şeklinde yorumlanmıştır. Böylelikle hataların birbirinden bağımsız olduğu sonucuna ulaşılmıştır. Ayrıca ÇÖDYÖÖ’ne ilişkin toplanan verilerin açımlayıcı faktör analizi için uygun olup olmadığına karar vermek için hesaplanan Bartlett testi sonucunda ki-kare değeri anlamlı bulunmuş ( $\chi 2$ $=7033,708 \mathrm{p}<0,05)$ ve KMO katsayısının da 0,953 olduğu görülmüştür. Tabachnick ve Fidell'e (2015) göre KMO değerin 1'e yaklaşması verilerin analiz için uygun olduğu anlamına gelmektedir. Bu durumda gerçekleştirilen ön analizler sonucunda verilerin açımlayıcı faktör analizine uygun olduğu sonucuna ulaşılmıştır. Bu sonuca göre parametre tahmini ve model uyum değerleri için de en çok olabilirlik tekniği (Robust Maximum Likelihood) kullanılmasına karar verilmiştir. Gerçekleştirilecek döndürme tekniğine karar verebilmek amacıyla faktör puanları arasındaki ilişkiler incelenmiş ve faktörler arasındaki ilişkiler; $p<0,05$ düzeyinde anlamlı olmadığından dik döndürme teknikleri arasında yer alan varimax döndürme tekniğinden yararlanılmıştır (Tabachnick ve Fidell, 2015).

Ayrıca, ölçme aracının yapısına karar verilmesi aşamasında maddelere ilişkin açıklanan ortak varyansın 0,40 'tan büyük olmasına ve maddelerin açıklanan faktör yüklerinin de $0,45^{\prime}$ ten büyük olmasına dikkat edilmiştir (Köklü, 2002; Çokluk, Şekercioğlu ve Büyüköztürk, 2010). Bu bağlamda dikkat edilen bir diğer husus ise bir maddenin iki farklı faktör altında 0,10 'dan daha küçük fark ile faktör yükü verip vermediğinin kontrol edilmesidir. Bu durumda olan madde ya da maddelerin ölçek formundan çıkartılması gerekmektedir (Büyüköztürk, 2014). Ölçeğin yapısı ortaya konulduktan sonra gerçekleştirilen doğrulayıcı faktör analizi ile de yapı sınanmış ve uyum iyiliği değerleri sunularak literatürde kabul gören kriterlere göre değerlendirilerek sunulmuştur. Ayrıca ölçekten toplam puan hesaplanıp hesaplanamayacağına kanıt olarak Mplus programı yardımıyla ikinci düzey DFA gerçekleştirilmiştir. Yetkinlikler ve Eksiklikler alt faktörleri arasında korelasyon katsayısı hesaplanmış $(\mathrm{r}=0,83)$ ve faktörler arasında pozitif yönde güçlü bir ilişki olduğu görülmüştür.

DFA ile Test edilen ölçme modeline ilişkin hesaplanan uyum indeksleri olan NFI, CFI, RFI ve NNFI değerlerinin de 0,90'dan yüksek olması ve SRMR değerinin 0,048 olarak hesaplanmış olması ölçme modelinin iyi bir uyuma sahip olduğunun bir göstergesi şeklinde yorumlanmaktadır (Çokluk, Şekercioğlu ve Büyüköztürk, 2018). Ayrıca hesaplanan diğer uyum indeksi olan RMSEA değerinin de 0,05 değerinden düşük olmasının arzu edilen bir durum olduğu (Jöröskog ve Sörbom, 1993) fakat bu değerin 0,10 değerinden düşük olmasının da kabul edilebilir olduğu ifade edilmektedir (Anderson ve Gerbing, 1984). Bu yönüyle bu değerin de kabul edilebilir olduğu ve sınanan ölçme modelinin doğrulandığı kabul edilmektedir.

\section{Bulgular}

\subsection{Açımlayıcı faktör analizine iliş̧kin bulgular}

27 tane maddenin açıklanan ortak varyansları incelenmiş ve 0,54 ile 0,81 arasında değişkenlik gösterdiği gözlenmiştir. Fakat bir maddenin iki faktör altında 0,10 'dan daha küçük bir farkla faktör yükü vermesi ve bir maddenin de bir alt faktör altında tek başına faktör yükü vermesi nedeniyle analizden çıkarılmıştır. Son durumda her bir maddenin açıklanan ortak varyans değerinin 0,40 'tan büyük olduğu teyit edilmiş ve kalan 25 madde ile analizler yürütülmüş̧ür. Daha sonra maddelere ilişkin faktör yükleri incelenmiş ve formda yer alan tüm maddelerin faktör yüklerinin 0,45 'ten büyük olduğu, faktörler altındaki madde sayılarının 3 'ten fazla olduğu ve farklı faktörler altında 0,10'dan daha küçük fark ile faktör yükü veren madde olmadığı görülmüştür (Tabachnick ve Fidell, 2015).

Bu bağlamda açıklanan toplam varyans miktarı ve öz değerler ile birlikte yamaç eğim grafiği dikkate alınarak ölçeğin faktör sayısına karar verilmiştir. Bu işlemlere ilişkin işlemler Tablo 2. ve Şekil 1.'de gösterilmektedir.

Tablo 2. Ölçeğin 25 maddelik formundaki faktör sayısı, faktörlere ilişkin özdeğer ve açıklanan varyans değerleri

\begin{tabular}{|c|c|c|c|c|c|c|c|c|c|}
\hline \multirow{2}{*}{ Bileşen } & \multicolumn{3}{|c|}{ Başlangıç değerleri } & \multicolumn{3}{|c|}{$\begin{array}{c}\text { Karesi alınan yüklerin toplam } \\
\text { çıarımı }\end{array}$} & \multicolumn{3}{|c|}{$\begin{array}{c}\text { Karesi alınan yüklerin döndürme } \\
\text { toplamı }\end{array}$} \\
\hline & Toplam & Varyans & $\begin{array}{l}\text { Birikimli } \\
\%\end{array}$ & Toplam & Varyans & $\begin{array}{l}\text { Birikimli } \\
\quad \%\end{array}$ & Toplam & Varyans & $\begin{array}{l}\text { Birikimli } \\
\%\end{array}$ \\
\hline 1 & 14,229 & 56,916 & 56,916 & 14,229 & 56,916 & 56,916 & 8,392 & 33,569 & 33,569 \\
\hline 2 & 2,245 & 8,979 & 65,895 & 2,245 & 8,979 & 65,895 & 8,081 & 32,326 & 65,895 \\
\hline
\end{tabular}

Tablo 2 incelendiğinde ölçekte yer alan toplam 25 maddenin iki faktör altında toplandığı görülmektedir. İki faktörün özdeğerlerinin sırasıyla birinci faktör 14,229; ikinci faktör 2,245 olduğu ve açıklanan toplam varyansın da \%65,895 olarak hesaplandığı görülmektedir. Sosyal bilimlerde gerçekleştirilen çok faktörlü yapılarda açıklanan toplam varyansın \%40-\%60 aralığında olmasının yeterli olarak kabul edildiği düşünüldüğünde bu değer oldukça iyidir (Scherer, Wiebe Luther ve Adams, 1988). Horn'un paralel analizi (1965) ile de desteklenen ölçeğin iki faktörlü yapısına ilişkin ek kanıt olarak çizdirilen yamaç eğim grafiğinin de Şekil 1.'deki gibi olduğu görülmüştür. Copyright (C) 2022 by IJSSER

ISSN: 2149-5939 
Şekil 1. Ölçeğin 25 maddelik deneme formunda yer alan faktörlere ilişkin yamaç eğim grafiği

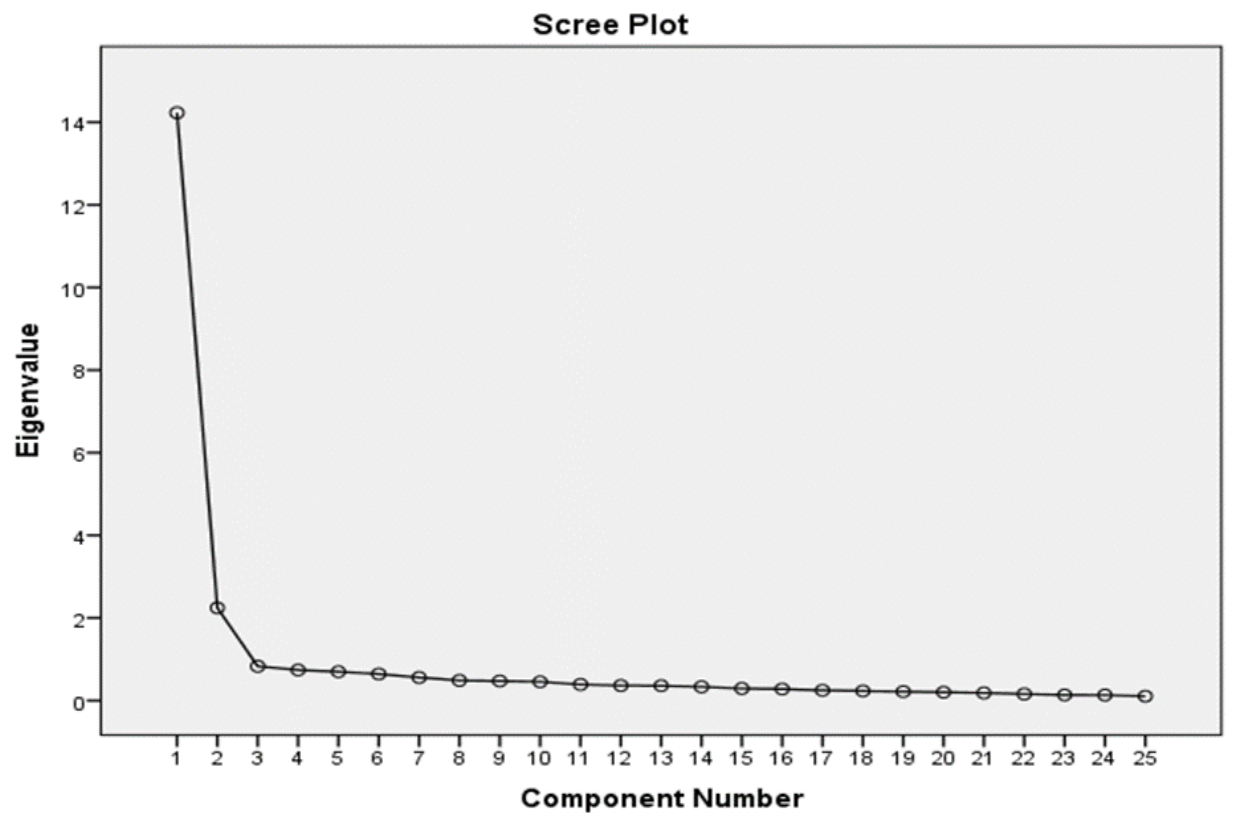

Şekil 1.'de yer alan yamaç eğim grafiği incelendiğinde eğimlerin gözle görülür bir şekilde kırılma gösterdiği iki faktörlü bir yapının desteklendiği görülmektedir. Bu bağlamda yamaç eğim grafiğginin özdeğeri açıklanan toplam varyans sonuçlarını destekleyerek ölçekte yer alan maddelerin iki faktör altında toplanmasının uygun olacağı görülmektedir. Ölçekte yer alan faktörler ve bu faktörlerin altında yer alan maddelere ilişkin varimax döndürme işlemi sonrasında elde edilen sonuçlar Tablo 3.'te sunulmaktadır.

Tablo 3. Ölçeğin 25 maddelik formuna ilişkin varimax döndürme sonrası faktör analizi sonuçları

\begin{tabular}{|c|c|c|}
\hline \multirow{2}{*}{ Maddeler } & \multicolumn{2}{|c|}{ Faktör yükleri } \\
\hline & Faktör 1 & Faktör 2 \\
\hline M10. Çevrimiçi ölçme değerlendirme sürecinde kazanımlara uygun alternatif etkinlikler oluşturabilirim. & ,828 & \\
\hline M33. Çevrimiçi ölçme değerlendirmede bilişsel becerileri sorgulamaya yönelik etkinlikler geliştirebilirim. & 808 & \\
\hline $\begin{array}{l}\text { M8. Çevrimiçi ögretim sürecinde gerçekleştireceğim ölçme değerlendirme etkinlikleri ile öğrenci ögrenmelerini } \\
\text { takip edebilirim. }\end{array}$ & ,779 & \\
\hline M22. Çevrimiçi ölçme değerlendirme etkinlerinde uygulama için uygun süreye karar verebilirim. & ,770 & \\
\hline M1. Geliştirdiğim ölçme değerlendirme etkinliklerini çevrimiçi ortamlara aktarabilirim. & ,764 & \\
\hline M21. Çevrimiçi ölçme değerlendirme uygulamaları ile öğrenci gelişimini objektif bir şekilde izleyebilirim. & ,761 & \\
\hline $\begin{array}{l}\text { M6. Çevrimiçi öğretim sürecinde öğrenci motivasyonunu artırmaya yönelik ölçme değerlendirme etkinlikleri } \\
\text { geliştirebilirim. }\end{array}$ &, 757 & \\
\hline $\begin{array}{l}\text { M30. Çevrimiçi ölçme değerlendirme materyali geliştirebileceğim internet sitelerini etkin bir şekilde kullanabi- } \\
\text { lirim. }\end{array}$ & ,752 & \\
\hline M20. Çevrimiçi sınav yapabileceğim uygulamalarda yaşadığım sorunları çözebilirim. & ,737 & \\
\hline M42. Çevrimiçi ölçme değerlendirme etkinliklerine çevrimiçi öğretim sürecinin her aşamasında yer verebilirim. & 690 & \\
\hline M17. Çevrimiçi öğrenme sürecinde öğrencilerin öğrenme eksiklerine göre uygun geri bildirim sağlayabilirim. & 689 & \\
\hline M5. Çevrimiçi ölçme değerlendirmeye ilişkin yaşadığım donanımsal sorunları çözebilirim. & 686 & \\
\hline $\begin{array}{l}\text { M14. Çevrimiçi öğrenme süreci başında öğrencileri tanımaya yönelik ne tür etkinlikler kullanacağıma karar ve- } \\
\text { rebilirim. }\end{array}$ & 623 & \\
\hline $\begin{array}{l}\text { M43. Çevrimiçi öğretim sürecinde ölçme değerlendirme etkinliklerine hangi aşamada yer vereceğimi belirle- } \\
\text { mekte zorlanırım. }\end{array}$ & & ,792 \\
\hline $\begin{array}{l}\text { M36. Çevrimiçi ölçme değerlendirmede öğrencilerin uygulama yapmalarına (model/maket oluşturma gibi) yö- } \\
\text { nelik etkinlik tasarlamakta zorlanırım. }\end{array}$ & & ,767 \\
\hline M44. Çevrimiçi ölçme değerlendirme etkinlikleri ile üst düzey düşünme becerilerini sorgulamakta zorlanırım. & & ,767 \\
\hline M48. Bireysel farklılıklara göre çevrimiçi ölçme değerlendirme etkinlikleri geliştirmekte zorlanırım. & & ,765 \\
\hline M32. Çevrimiçi ölçme değerlendirme etkinliklerinde ders içeriğinin tamamını sorgulamakta zorlanırım. & & ,757 \\
\hline M45. Çevrimiçi ölçme değerlendirmede akran değerlendirme etkinliklerine yer vermekte zorlanırım. & & ,755 \\
\hline M12. Alternatif ölçme değerlendirme tekniklerini çevrimiçi ortamlarda uygulamakta zorlanırım. & & ,752 \\
\hline M16. Çevrimiçi öğrenme sürecinde öğrencilerin öğrenme eksiklerini belirlemekte zorlanırım. & & ,729 \\
\hline $\begin{array}{l}\text { M47. Çevrimiçi ölçme değerlendirme etkinliklerini gerçekleştirirken her öğrencinin gerekli teknolojik araçlara } \\
\text { erişebilirliğini göz önünde bulundurmakta zorlanırım. }\end{array}$ & & ,721 \\
\hline $\begin{array}{l}\text { M24. Çevrimiçi ögrretimde alternatif ölçme değerlendirme tekniklerine (proje, portfolyo, performans vb.) yer } \\
\text { vermekte zorlanırım. }\end{array}$ & & ,720 \\
\hline M34. Çevrimiçi ölçme değerlendirme etkinlikleri ile duyuşsal becerileri sorgulamakta zorlanırım. & & ,714 \\
\hline $\begin{array}{l}\text { M7. Çevrimiçi öğretim sürecinde öğrenci motivasyonunu canlı tutacak ölçme değerlendirme etkinliklerine yer } \\
\text { vermekte zorlanırım. }\end{array}$ & & 622 \\
\hline
\end{tabular}


Tablo 3'te maddeler deneme formunda yer aldıkları sıra numaraları ile birlikte açımlayıcı faktör analizi sonucunda hesaplanan faktör yüklerine göre her faktör için büyükten küçüğe doğru sıralanarak verilmiştir. Buna göre Tablo 3. incelendiğinde ÇÖDYÖÖ için son durumda maddelerin iki faktör altında vermiş oldukları yüklerin 0,622 ile 0,828 arasında değişkenlik gösterdiği görülmektedir. Bu bağlamda madde yüklerinin 0,400 'ün üzerinde olması ölçeği oluşturan maddelerin ayırt ediciliğinin yüksek olduğunu ve ölçeğin ölçülmek istenilen özellik ile aynı yönde tutarlı bir dağılıma sahip olduğunu göstermektedir (Büyüköztürk, 2014).

Döndürme sonrası faktör yükleri ve faktörlerdeki maddelerin taşıdıkları anlam göz önünde bulundurularak faktörler isimlendirilmiştir. Faktörlerin kendi içerisinde yer alan madde özellikleri açısından incelendiğinde birinci faktörün olumlu, ikinci faktörün ise olumsuz maddelerden oluştuğu görülmüştür. Bu bağlamda birinci faktörün çevrimiçi ölçme ve değerlendirmeye yönelik güçlü yönleri ifade etmesi açısından "Yetkinlikler (Proficiency)" ve ikinci faktörün de zayıf ya da eksik görülen yönleri ifade etmesi açısından "Eksiklikler (Defíciency)" olarak isimlendirilmesi uygun görülmüştür. Analizler gerçekleştirilirken daha anlaşıllır olması için faktör isimlerinin ingilizce karşılıklarının kısaltması kullanılmıştır.

Elde edilen alt faktörlere sırasıyla; "Yetkinlikler (Proficiency)" (10, 33, 8, 22, 1, 21, 6, 30, 20, 42, 17, 5 ve 14 nolu maddeler) ve "Eksiklikler (Deficiency)" (43, 36, 44, 48, 32, 45, 12, 16, 47, 24, 34 ve 7 nolu maddeler) isimleri verilmiştir. Ölçeği oluşturan alt faktörler ve bu faktörler altında gruplanan maddeler Tablo 4 'te ifade edilmektedir.

Tablo 4. Faktörler ve faktörler altında yer alan maddeler

\begin{tabular}{lllc}
\hline & Faktörler & Maddeler & Toplam madde say1s1 \\
\hline Faktör 1 & Yetkinlikler (Proficiency) & M10, M33, M8, M22, M1, M21, M6, M30, M20, & 13 \\
& & M42, M17, M5, M14 \\
Faktör 2 & Eksiklikler (Deficiency) & $\begin{array}{l}\text { M43, M36, M44, M48, M32, M45, M12, M16, } \\
\text { M47, M24, M34, M7 }\end{array}$ & 12 \\
\hline
\end{tabular}

Tablo 4 incelendiğinde "Yetkinlikler (Proficiency)" olarak adlandırılan birinci faktör altında 13 ve "Eksiklikler (Deficiency)" olarak adlandırılan ikinci faktör altında 12 madde yer aldığı görülmektedir. Ayrıca birinci faktör altında gruplanan tüm maddelerin anlamca olumlu, ikinci faktör altında gruplanan tüm maddelerin de anlamca olumsuz olduğu, bu yönüyle de ölçeğin toplamda 13 olumlu ve 12 olumsuz olmak üzere dengeli bir dağılıma sahip olduğu görülmektedir. Ayrıca "Eksiklikler (Deficiency)" faktörü altında yer alan maddeler yeniden kodlama işlemine tabi tutulduğu için faktörler arasındaki korelasyon pozitif ve 0,83 olarak hesaplanmıştır.

\subsection{Doğrulayıcı faktör analizine ilişskin bulgular}

Ölçeğin açımlayıcı faktör analizi sonrasında açığa çıkan ve karar verilen yapısının doğrulanması amacıyla benzer özelliklere sahip farklı bir çalışma grubundan elde edilen veriler ile doğrulayıcı faktör analizi çalışması gerçekleştirilmiştir. Bu bağlamda gerçekleştirilen doğrulayıcı faktör analizine ilişkin standartlaştırılmış değerlerin ve t değerlerinin yer aldığı yol diyagramı Şekil 2.'de gösterilmektedir.

Şekil 2. incelendiğinde tüm $t$ değerlerinin istatiksel olarak anlamlı olduğu $(p<, 01)$ ve standartlaştırılmış değerlerin de 0,43 ile 0,87 arasında değişkenlik gösterdiği görülmektedir. Bu bağlamda ayrıca doğruluğu sınanmaya çalışılan ölçme modeli sonucunda hesaplanan çeşitli uyum indeksleri Tablo 5.'te ifade edilmektedir.

Tablo 5. DFA Uyum İndeksleri

\begin{tabular}{lllllll}
\hline$\chi 2_{(592,76)} / \operatorname{sd}_{(274)}$ & RMSEA & NFI & CFI & RFI & NNFI & SRMR \\
\hline 2,16 & 0,076 & 0,97 & 0,98 & 0,97 & 0,98 & 0,048 \\
\hline
\end{tabular}

Test edilen ölçme modeline ilişkin hesaplanan uyum indeksleri Tablo 5.'te görüldüğü gibidir. Hesaplanan değerler incelendiğinde $\chi 2(592,76) / \mathrm{sd}(274)$ değerinin manidar $(\mathrm{p}<, 01)$ ve $\chi 2 / \mathrm{sd}=2,16$ olarak hesaplanmış olması dolayısıyla modelin kabul edilebilir bir uyum iyiliğine sahip olduğu söylenebilir. Hesaplanan uyum indeksleri olan NFI $(0,97)$, CFI $(0,98)$, RFI $(0,97)$ ve NNFI $(0,98)$ değerlerinin de 0,90 'dan yüksek olması ve SRMR değerinin de 0,048 olarak hesaplanmış olması ölçme modelinin iyi bir uyuma sahip olduğunun bir göstergesi şeklinde yorumlanmaktadır (Çokluk, Şekercioğlu ve Büyüköztürk, 2018). Ayrıca Tablo 5.'te yer alan diğer uyum indeksi olan RMSEA $(0,076)$ değerinin de 0,05 değerinden düşük olmasının arzu edilen bir durum olduğu (Jöröskog ve Sörbom, 1993) fakat bu değerin 0,10 değerinden düşük olmasının da kabul edilebilir olduğu ifade edilmektedir (Anderson ve Gerbing, 1984). Bu yönüyle bu değerin de kabul edilebilir olduğu ve sınanan ölçme modelinin doğrulandığı kabul edilmektedir. Elde edilen modele ilişkin ikinci düzey DFA bulguları Şekil 3.'te sunulmuştur. 
Şekil 2. Gerçekleştirilen doğrulayıcı faktör analizinde path diyagramına ilişkin standartlaştırılmış değerler ve $t$ değerleri
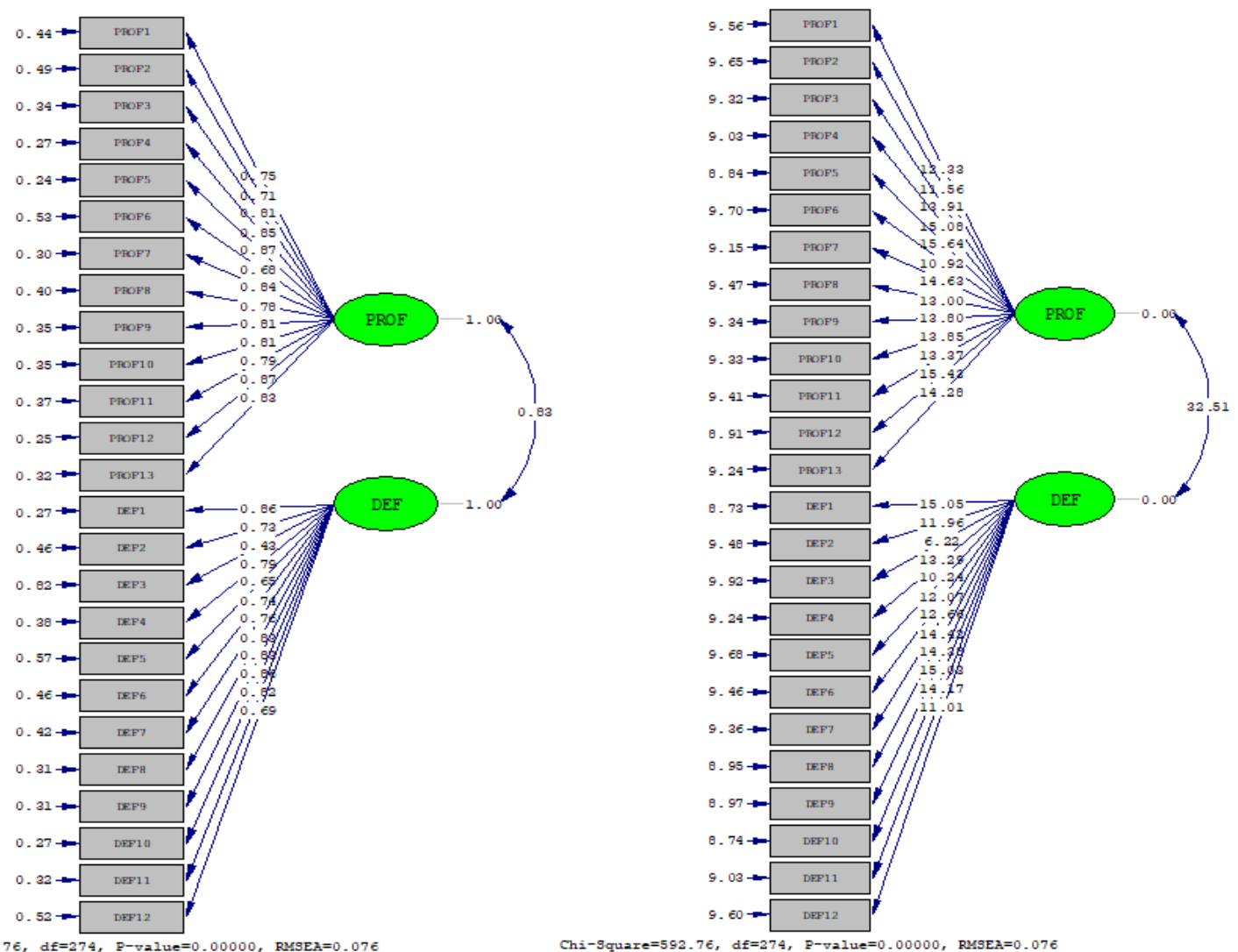

Şekil 3. İkinci Düzey DFA

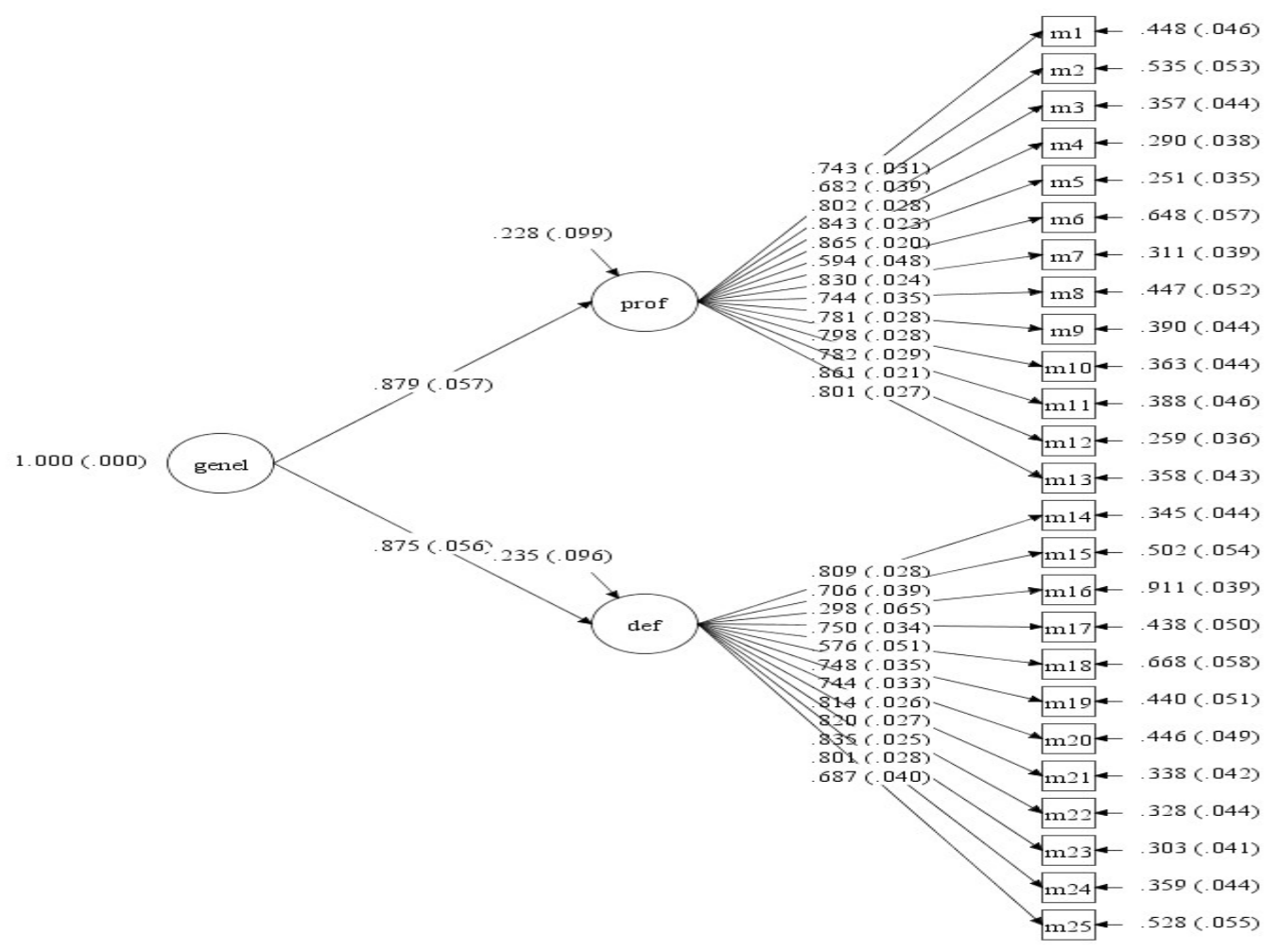


Ayrıca DFA verilerine ilişkin değerler yardımıyla her bir faktör için yakınsak ve ıraksak geçerlik değerleri hesaplanmıştır. Bu bağlamda öncelikle her bir faktör altında yer alan maddelerin standart yük değerlerinin kareleri toplamının gerçek yük değerlerinin toplamına (gözlenen değer+hata varyansı) bölünmesiyle elde edilen birleştirici güvenirlik (CR) değerleri sırasıyla 0,95 ve 0,93 olarak hesaplanmıştır. Yakınsak ve ıraksak geçerliğe ilişkin faktörlerin Average Variance Extracted (AVE) değerleri sırasıyla 0,611 ve 0,537 olarak hesaplanmıştır. Her iki faktör için bu değerin $0,5^{\prime}$ ten büyük olma koşulunu sağladığı fakat ikinci faktör için AVE değerinin MSV $(0,5929)$ değerinden küçük olması ıraksak geçerliğin tam anlamıyla sağlanmadığını göstermektedir. Fakat bu değerin hesaplanan AVE değerine oldukça yakın olması nedeniyle kabul edilebilir şeklinde yorumlanmıştır. Sonuç olarak ölçeğin yakınsak ve ıraksak geçerlik koşulunu sağladığı görülmüss ve ölçekte yer alan ve 2 faktör altında dağılım gösteren maddelerin birbirleriyle ve oluşturdukları yapı ile ilişkili oldukları gözlenmiştir.

\subsection{Güvenirliğe iliş̧kin bulgular}

ÇÖDYÖÖ'nin 25 madde ve iki alt faktörden oluşan nihai formu için AFA ve DFA çalışma gruplarından elde edilen veriler ile Jamovi (1.8.1) programı yardımıyla iç tutarlık anlamındaki Cronbach alfa güvenirlik katsayısı ve McDonald's Omega katsayısı hesaplanmıştır. Güvenirlik kanıtı olarak eğitim ve psikolojide en sık kullanılan güvenirlik katsayılarından biri olarak ifade edilen Cronbach alfa ölçme aracında yeterli sayıda madde yer alması ve ölçme aracının tek boyuttan oluşması durumunda gerçek güvenirlik değerine oldukça yakın bir sonuç vereceği belirtilmektedir (Cronbach, 1951). Cronbach adı ile ifade edilse de aslında Guttman (1945) tarafindan gerçekleştirilen çalışmalar sonucunda ortaya atılan Cronbach alfa katsayısı aynı zamanda "güvenirliğin alt sınırı olarak ifade edilmektedir (Sijtsma, 2009). Cronbach alfaya alternatif olarak geliştirilen güvenirlik katsayılarından biri olan Omega katsayısı Yurdugül (2006) da McDonald tarafindan geliştirilmiş ve maddelere ait faktör yükleri esas hesaplanmaktadır (McDonald, 1999). Omega katsayısı, güvenirlik hesaplamalarında genellikle Cronbach alfaya eşit ya da daha yüksek değer vermektedir (Kula Kartal ve Mor Dirlik, 2016). Bu bağlamda geliştirilen ölçeğe ilişkin AFA ve DFA çalışma gruplarından elde edilen veriler ile hesaplanan iki güvenirlik katsayısına ilişkin değerler da Tablo 6.'da sunulmaktadır.

Tablo 6. ÇÖDYÖÖ ve alt boyutlara ilişkin hesaplanan $\alpha$ ve $\omega$ değerleri

\begin{tabular}{lcccccc}
\hline & \multicolumn{2}{c}{ Yetkinlikler (Proficiency) } & \multicolumn{2}{c}{ Eksiklikler (Deficiency) } & \multicolumn{2}{c}{ Genel } \\
\cline { 2 - 7 } AFA Verileri & $\alpha$ & $\omega$ & $\alpha$ & $\omega$ & $\alpha$ & $\omega$ \\
\cline { 2 - 7 } & 0,955 & 0,955 & 0,949 & 0,949 & 0,966 & 0,966 \\
\hline DFA Verileri & 0,950 & 0,953 & 0,925 & 0,930 & 0,958 & 0,962 \\
\hline
\end{tabular}

İç tutarlık anlamında güvenirliğin tespit edilmesinde yaygın olarak kullanılan Cronbach alfa katsayısının 0,700 üzerinde olması beklenmektedir (DeVellis, 2012). Bu bağlamda ÇÖDYÖÖ için hesaplanan değerlerin ölçeğin çok iyi bir iç tutarlığa sahip olduğunun bir göstergesi olarak kabul edilebileceği düşünülmektedir. Bu bağlamda AFA ve DFA verileri kullanılarak ayrı ayrı hesaplanan değerler ölçeğin iç tutarlık anlamında genel ve alt boyutlar bazında güvenirliğinin oldukça yüksek olduğunu göstermektedir.

Ayrıca alt faktörlere yönelik olarak DFA verileri ile hesaplanan birleştirici güvenirlik katsayıları "Yetkinlikler" alt faktörü için 0,95 ve "Eksiklikler" alt faktörü için 0,93 olarak hesaplanmıştır. Farklı veri setleri üzerinden ayrı ayrı gerçekleştirilen güvenirlik analizleri sonucunda elde edilen bu değerler, ölçek aracılı̆̆ıyla elde edilecek verilerin güvenilir sonuçlar sağlayacağı şeklinde yorumlanabilir.

\section{Tartışma ve sonuç}

ÇÖDYÖÖ'nin geliştirilmesine ilişkin geçerlik çalışmaları, kapsam ve yapı geçerliği yoluyla sağlanmaya çalışılmışıır. Kapsam geçerliğinin sağlanmasına yönelik ölçme değerlendirme ve fen bilgisi eğitimi alanından toplam dokuz uzmanın görüşü alınmış ve bu görüşler doğrultusunda kapsam geçerlik oranları ve kapsam geçerlik indeksleri hesaplanmıştır. Ölçeğin geliştirilme sürecinde de ifade edildiği üzere hesaplanan değerlerin kritik değer ile karşılaştırılması sonucu deneme formunda yer alacak maddelere karar verilmiştir. Ölçeğin yapı geçerliğinin test edilmesinde ise açımlayıcı faktör analizinden yararlanılmış, gerçekleştirilen analizler sonucunda 25 maddeden oluşan formun iki faktörlü bir yapı gösterdiği sonucuna ulaşılmışırı. Ayrıca faktörlere ilişkin hesaplanan özdeğerler Horn'un paralel analizi (1965) ile de teyit edilerek iki faktörlü yapının korunmasına karar verilmiştir. Ölçeğe ilişkin güvenirlik çalışması ise maddeler düzeyinde ve alt faktörler düzeyinde Cronbach alfa ve McDonald omega katsayıları hesaplanarak belirlenmeye çalışılmıştır. Ayrıca hesaplanan birleştirici güvenirlik katsayısı, yakınsak ve ıraksak geçerlik değerleri her bir maddenin ve alt faktörün belirlenen yapıyı oldukça iyi düzeyde temsil ettiğin göstermektedir. Ölçeğin doğrulanan yapısına ilişkin hesaplanan Cronbach alfa katsayısının 0,958 ve alt faktörlere 
ilişkin hesaplanan değerlerin de sırasıyla 0,950 ve 0,925 ; McDonald omega katsayısının da 0,962 ve alt faktörlere ilişkin hesaplanan değerlerin de sırasıyla 0,953 ve 0,930 olması bu duruma kanıt olarak sunulabilmektedir. Ayrıca faktör araştırmaları incelendiğinde güvenirlik ile ilgili ifade edilen bir diğer kriterin ölçekte yer alan faktör $(\mathrm{Q})$ sayısının madde sayısına (P) oranının (Q/P) 0,30'dan küçük olması gerektiğidir (Haksitian, Rogers ve Cattel, 1982; Akt. Stevens, 2002). Bu durum da göz önünde bulundurulduğunda ölçek için hesaplanan değerin $(2 / 25=0,08)$ bu kritere uygun olduğu sonucuna ulaşılmıştır.

Ölçeğin geliştirilme sürecine ilişkin olarak oluşturulan deneme formu 49 maddeden oluşmaktadır. Veri toplama işlemleri sonrasında gerçekleştirilen analizler sonucunda son durumda 25 maddenin ölçekte tutulmasına ve belirlenen kriterleri sağlamayan 24 maddenin ise ölçekten çıkartılmasına karar verilmiştir. Bu durumda ölçekte kalan 25 maddenin ise açımlayıcı faktör analizi sonucunda elde edilen yamaç eğim grafiği ve madde yük değerleri göz önünde bulundurularak 2 faktör altında gruplandığı görülmektedir. Birinci faktör "Yetkinlikler" olarak adlandırılmakta ve toplam 13 maddeden oluşmaktadır. İkinci faktör "Eksiklikler" olarak adlandırılmakta ve toplam 12 maddeden oluşmaktadır. Açımlanan bu yapı doğrulayıcı faktör analizi ile sınanmış ve hesaplanan standarlaştırılmış yük değerlerinin 0,43 ile 0,87 arasında değişkenlik gösterirken tüm $t$ değerlerinin de istatistiksel olarak anlamlı olduğu görülmüşsür. Ayrıca hesaplanan uyum indekslerinin de mükemmel/kabul edilebilir düzeyde olduğu görülmüştür. Bu haliyle 2 faktör altında 13 olumlu ve 12 olumsuz maddeden ve 10 dereceli puanlamadan oluşan "Çevrimiçi Ölçme ve Değerlendirmeye Yönelik Özyeterlik Ölçeği”nin bilimsel ve psikometrik açıdan geçerli ve güvenilir bir ölçme aracı olduğu ve cevaplanmasıyla uzaktan eğitimde öğretici konumunda bulunan bireylere ilişkin özyeterlik puanını geçerli ve güvenilir bir şekilde açığa çıkarması beklenmektedir.

\section{Yazarların katkı oranı}

Yazarlar makalenin veri toplama, verilerin çözümlenmesi, raporlaştırma ve diğer aşamalarından eşit düzeyde sorumlu olduğunu beyan ederler.

\section{Çıkar çatışması}

Bu çalışmada yazarlar tarafindan herhangi bir çıkar çatışması belirtilmemiştir.

\section{Etik kurul beyanı}

Bu çalışmanın Etik Kurul Onayı, 05.04.2021 tarih ve 04 sayılı karar ile Mersin Üniversitesi Sosyal ve Beşeri Bilimler Etik Kurulu'ndan alınmıştır.

\section{Kaynakça}

Anderson, J. C. ve Gerbing, D. W. (1984). The effect of sampling error on convergence, improper solutions, and goodness-offit indices for maximum likelihood confirmatory factor analysis. Psychometrika, 49(2), 155-173.

Atılgan, H. (2009). Eğitimde ölçme ve değerlendirme (4. Baskı). Ankara: Anı Yayıncılık.

Balcı, E. ve Tekkaya, C. (2000). Ölçme ve Değerlendirme Tekniklerine Yönelik Bir Ölçeğin Geliştirilmesi, Hacettepe Üniversitesi Eğitim Fakültesi Dergisi, 18, 42-50.

Balta, Y. ve Türel, Y. K. (2013). Çevrimiçi Uzaktan Eğitimde Kullanılan Farklı Ölçme Değerlendirme Yaklaşımlarına İlişkin Bir İnceleme. Electronic Turkish Studies, 8(3).

Bandura, A. (1986). Social foundations of thought and action: A social cognitive theory. Englewood Cliffs, NJ: Prentice-Hall. Büyüköztürk, Ş. (2014). Sosyal bilimler için veri analizi el kitabı. Ankara: Pegem Akademi.

Coşkun, M. ve Mardikyan, S. (2016). Çevrimiçi Ölçme ve Değerlendirme Sistemlerinin Gerçekleşen Kullanımını Belirleyici Faktörler: Bir Yapısal Eşitlik Modellemesi (YEM) Çalışması. Eğitim ve Bilim, 41(188).

Cronbach, L. J. (1951). Coefficient alpha and the internal structure of tests. Psychometrika. 16, 297-334.

Çokluk, Ö., Şekercioğlu, G. ve Büyüköztürk, Ş. (2018). Sosyal bilimler için çok değişkenli istatistik: SPSS ve LISREL uygulamaları (Vol. 5). Ankara: Pegem Akademi.

Demirel, Ö. (2006). Planlamadan Değerlendirmeye Öğretme Sanatı, Ankara: PegemA Yayıncılık.

DeVellis, R. F. (2012). Scale Development: Theory and applications (3rd edn). Thousand Oaks, California: Sage.

DeVellis, R. F. (2016). Scale development: Theory and applications. London, UK: Sage.

Gawith, G. (1995). A Serious Look at Self-Efficacy: Or Waking Beebing Slooty. October 23, 2003.

Guttman, L. (1945). A basis for analyzing test-retest reliability. Psychometrika, 10, 255-282.

Gülbahar, Y. (2012a). E-Öğrenme. Ankara: Pegem Akademi. 
Horn, J. L. (1965). A rationale and test for the number of factors in factor analysis. Psychometrika, 30, 179-185.

Jöreskog, K. G. ve Sörbom, D. (1993). LISREL 8: Structural equation modeling with the SIMPLIS command language. Scientific Software International.

Kapucu, N. K. ve Adnan, M. (2018). Uzaktan Öğretimde Çevrimiçi Eğitmen Başarısının Değerlendirilmesi. Journal of Hasan Ali Yücel Faculty of Education/Hasan Ali Yücel Eğitim Fakültesi Dergisi (HAYEF), 15(1).

Köklü, N. (2002). Açıklamalı istatistik terimleri sözlüğ̈̈. Ankara: Nobel Yayıncılık.

Kula Kartal, S. ve Mor Dirlik, E. (2016). Geçerlik kavramının tarihsel gelişimi ve güvenirlikte en çok tercih edilen yöntem: Cronbach Alfa Katsayısı. Abant İzzet Baysal Üniversitesi Eğitim Fakültesi Dergisi, 16(4), 1865-1879.

McDonald R. P. (1999). Test theory: a unified treatment. Mahwah, NJ: LEA Publisher.

Odabaş, H. (2003). İnternet tabanlı uzaktan eğitim ve bilgi ve belge yönetimi bölümleri. Türk Kütüphaneciliği. Vol. 17, n. 1, pp. 22-36.

R Core Team (2021). R: A Language and environment for statistical computing. (Version 4.0) [Computer software]. Retrieved from https://cran.r-project.org. (R packages retrieved from MRAN snapshot 2021-04-01).

Raykov, T. (1998). Coefficient Alpha And Composite Reliability With Interrelated Nonhomogeneous Items. Applied Psychological Measurement, 22 (4): 375-385.

Revelle, W. (2019). psych: Procedures for Psychological, Psychometric, and Personality Research. [R package]. Retrieved from https://cran.r-project.org/package=psych.

Sarı, H. İ. (2020). Evde kal döneminde uzaktan eğitim: Ölçme ve değerlendirmeyi neden karantinaya almamalıyız? Uluslararası Eğitim Araştırmacıları Dergisi, 3(1), 121-128.

Scherer, R. F., Luther, D. C., Wiebe, F. A. ve Adams, J. S. (1988). Dimensionality of coping: Factor stability using the ways of coping questionnaire. Psychological Reports, 62(3), 763-770.

Sjtsma, K. (2009). On the use, the miuse, and the very limited usefulness on Cronbach's alpha. Psychomterika. 74(1), 107-120.

Stevens, J. P. (2002). Applied multivariate statistics for the social sciences. (Dördüncü baskı). Psychology Press.

Tabachnick, B. G. ve Fidel, L. S. (2015). Using Multivariate Statistics.,(Baloğlu, M., Çev. Ed.). Ankara: Nobel Yayıncılık.

Toker, N. (2005). Eğitimde Ölçme ve Değerlendirmenin Kullanımı ve Önemi, (http://www.egitim.com.tr/) (Erişim Tarihi: 05.06.2020).

The jamovi project (2021). jamovi. (Version 1.8) [Computer Software]. Retrieved from https://www.jamovi.org.

Yurdugül, H. (2005). Ölçek geliştirme çalışmalarında kapsam geçerliği için kapsam geçerlik indekslerinin kullanılması. XIV. Ulusal Ĕ̈itim Bilimleri Kongresi, 1, 771-774.

Yurdugül, H. (2006). Paralel, eşdeğer ve konjenerik ölçmelerde güvenirlik katsayılarının karşılaştırılması. Ankara Üniversitesi Ĕ̈itim Bilimleri Fakültesi Dergisi. 39(1), 15-37. 


\section{Extended Abstract}

\section{Introduction}

The measurement of the distance training process is mainly continued to assess the importance of measuring the measurement, to not measure the student success as required by giving random memo by giving the same grades to everyone will significantly affect the decisions to be given about students by giving the same grades. In this context, in this context, it is obvious that the measurement and evaluation approaches in accordance with the study of the study and evaluation approaches in accordance with the philosophy of the training approach.

In the process of measuring and evaluation activities of online education teaching activities, in the Covid-19's epidemic in the online education teaching in the online education teaching in the online education teaching, the actual measurement of the tutorial measurement of the tutorial measurement is also forefront. In this sense, in order to maintain online measurement evaluation activities in a healthy shape, it is considered important to be important in the tutorial position. In this context, this study is thought that this study will contribute to the literature.

\section{Method}

This research was carried out over two different independent working groups to carry out the research exploratory and verifier factor analyzes. For both groups, the study group consists of teachers and instructors in general in 2020-2021 education in education in the distance education system. Analysis of 316 data was carried out to test the counters of explanatory factor analysis, which is used in the framework of research and multivariate statistical analysis techniques. After the exploratory factor analysis, confirmatory factor analysis for testing the decided structure was performed on 202 data obtained from an independent study group with similar properties.

\section{Findings, discussion and results}

348 the data set for the test form consisting of the participant's data is incomplete or incorrect data. In this case, the total amount of 22 items determined by the multi-connection problem were removed from the trial form and the analysis was continued with 27 items remaining in the trial form. The Durbin Watson coefficient calculated to test the independence of the errors is an expected situation to receive approximately 2.50 values. In this context, it was seen that the calculated value was approximately 3.00 was interpreted in the form of an acceptable. Thus, the errors are independent of each other. In addition, the Bartlett test, was significant $(\chi 2=7033,708 \mathrm{p}<0.05)$ and KMO coefficient was 0.953. According to Tabachnick and Fidell (2015), the KMO to approach the KMO value 1 means that the data is suitable for analysis. In this case, the result of the data is appropriate to the factor analysis. The relationships between factor scores were examined and the relationships between factors; in order to decide the rotation technique to be performed. The VariMax return technique, which is one of the steep rotation techniques since $\mathrm{p}<0.05$ is not significant.

27 The common variances described in the article were examined and were observed that 0.54 to 0.81 varies. However, it was analyzed due to the factor burden at a difference of 1 substance in a difference of less than 0.10 under two factors and the 1 item gives the factor load under a sub-factor. In the last case, the common variance described by each substance was confirmed to be greater than 0.40 and analyzes with the remaining 25 items were carried out. Then the factor loads on the substances were examined and the factor load of the factor loads of each substance in the trial form is greater than 0.45 and the number of substances under factors are more than 3 and less than 0.10 difference in different factors. It was observed that there was no substance.

The confirmatory factor analysis study was carried out on a different study group to verify the structure of the scale exposed and the decided structure. When the compliance indices calculated on the tested measurement model are examined, $\chi 2(563,47) / \mathrm{sd}(274)$ can be expressed very well because it is smaller than 5 . The fact that NFI, CFI, RFI and NNFI values calculated from the modification are greater than 0.90 of the CFI, RFI and NNFI and the SRMR value is considered to be a good compliance. In addition, with the help of the values for DFA data, convergent and divergent validity values were calculated for each factor. In this context, the combining reliability coefficients (CR) of factors (CR) was calculated as 0.95 and 0.93 respectively. Average Variance Extracted (AVE) values of the factors for converging and divergent valid are calculated as 0.611 and 0.537 respectively.

As such, the "Self-Efficacy Scale for Online Assessment and Evaluation", which consists of 13 positive and 12 negative items and 10-point scoring under 2 factors, is thought to be a scientifically and psychometrically valid and reliable measurement tool. 